\title{
Reading through Interaction: From Individualistic Reading Comprehension to Collaboreading
}

\author{
Fatemeh Behjat \\ Islamic Azad University, Abadeh Branch, Abadeh, Iran \\ Email: fb_304@yahoo.com
}

\begin{abstract}
Group work and interaction play significant roles in the learning process and much of the evidence comes from studies of foreign language learners' interaction with native speakers. This study aimed at finding out whether interaction among learners also facilitates reading comprehension. For this purpose, a number of Iranian EFL students at Abadeh and Shiraz Islamic Azad Universities were selected and divided into two groups. While in the first group individualistic reading was encouraged, the second group read together and had interaction and collaboration in understanding the texts. The results revealed that collaboreading improves the learners' comprehension better than individualistic reading.
\end{abstract}

Index Terms - reading comprehension, interaction, collaboreading, individualistic reading

\section{INTRODUCTION}

Reading comprehension is considered as a process which involves the integration of decoding ability, vocabulary knowledge, background knowledge and the use of a set of strategies to make sense of a text and understand it (Kintsch and Kintch, 2005), and it is one of the basic activities done in every language classroom since it functions as a means of increasing learners' knowledge of the language being learnt.

What the teachers do is to help the learners develop their reading habits in order to understand the texts with no reference to their native language translation. There are different strategies followed in language classrooms. Block and Pressley (2002) pointed out that there are over thirty cognitive and metacognitive processes involved including meaning clarification, summarizing, predicting and so on. Duffy (1993) defines reading strategies as "plans for solving problems encountered in constructing meaning" (p. 232). According to Trabasso and Bouchard (2002), comprehension strategies are specific, learned procedures which strengthen active, competent and intentional reading. These strategies can range from vocabulary search, or looking up the unknown words in a dictionary to more comprehensive actions, that is, making links between what is read and the learners' background knowledge. They are referred to as cognitive strategies (Oxford, 1996; cited in Carter and Nunan, 2002).

Jimenez, Garcia, and Pearson (1995) point out that using different strategy types depends on the level of readers. More proficient ones know many strategies and use each of them in a certain way. Yet, these strategies are teachable and evidence shows that when they are taught, they can strengthen students' performance in tests of comprehension and recall (Pearson and Fielding, 1991).

Learning strategies not only help learners to be autonomous and independent learners but they also increase selfefficacy (Bandura, 1997). Oxford (1996) contends that among different language learning strategies such as cognitive, mnemonic, affective, social and metacognitive strategies, metacognitive strategies help learners manage themselves as learners, the general learning process and specific learning tasks. While some learning tasks direct learners to be independent learners and learn individually, some others foster learning through interaction and cooperation. As for reading comprehension, Himes (2007) for example mentions that cooperative strategies which help the students work together to learn will improve reading comprehension significantly. Renandya and Jacobs (2002) also offer a set of activities in which language learners can be involved in for the better comprehension of a text. They include both individualistic tasks such as copying interesting words and expressions into a notebook or writing a letter to the author and talk about the content of the book as well as tasks which require participation in group work and interaction such as sharing views about the content of the book with classmates, reading interesting parts aloud, or role-playing the story.

Following Himes (2007) and Renandya and Jacobs (2002), the present study aimed at finding out whether using individualistic activities and reading independently from peers will foster reading comprehension to the same extent as reading through interaction and participation in group work. In other words, the main objective of the present study was to see which one improves EFL learners' reading comprehension more: individualistic reading or collaboreading. The second goal of this study was to see whether males or females could improve their reading comprehension better through individualistic reading and collaboreading.

\section{LITERATURE REVIEW}


Glancing back at the history of language teaching, one would find that reading skill was sometimes considered a passive skill as the reader is not involved in any kind of language production in the same way as a speaker or a writer is. Then, there was a shift in emphasis from being passive to active. Being defined as the process of activation of knowledge to accomplish an exchange of information (Chastain, 1990), reading comprehension is now considered an active decoding skill as he reader is expected to arrive at the meaning of the message of the language as a code. It has been a long time since researchers considered reading as a process in which the reader uses his background knowledge in order to recreate the writer's intended meaning. Once again, in recent years the ground shifted to think of reading as interactive rather than simply active skill because meaning is partial in the text and what is intended by the writer might not be interpreted the same way by the reader. In other words, readers negotiate meaning. This perspective considers the text, the reader, and the social context in which the activity of reading takes place (Celce-Murcia, 2001).

Since reading skill is one of the basic language aspects the foreign language learners need to work on from the early days of their long journey of language learning, it is under the special focus for both language teachers and researchers. Depending on the perspectives adopted by teachers, reading can be considered as practice, product, or process (Wallace, 1992). If reading is linked to everyday life uses, it is a practice, if the focus is on the form and meaning of the written text, reading is a product, and if attention is on the reader who is involved in the processing of written language and the strategies he uses to draw meaning out of the text, reading is a process. Since the third orientation is usually adopted in language classrooms, teachers take into account the processes language learners are involved in and strategies they use to come to the intended meaning of the writer.

Weaver (1994) classifies approaches to reading comprehension into two categories. Part-centered or code-emphasis approach views reading instruction as moving the learning from part to the whole. This is what is sometimes referred to as bottom-up. Meaning-emphasis or top-down approaches emphasize the construction of meaning from the whole texts and then draws on both the reader and writer's schemata or background knowledge and personal experiences. According to Carter and Nunan (2002), taking reading as a process means that we should consider it a top-down phenomenon since it sheds light on the kind of background knowledge the reader brings to reading. In contrast with the text-based or bottom-up approach in which the language forms required to comprehend the text are taught, top-down or inside-the-head approach implies that reading comprehension is based on the students' knowledge base. The stronger a learner's background knowledge is, the more comprehension will be achieved through reading.

In order to process the information in a top-down fashion, a set of strategies need to be applied. According to Dörnyei and Ottó (1998), as the goal of each strategy is "the engine that fires language learning action and provides the direction for the action", the theory of language learning which is adopted by the learner to achieve his goal is the tapestry approach (Scarcella and Oxford, 1992). This approach reflects Vygotsky's (1986) view that learning occurs in interaction with other people. That is, in order to achieve the goal of processing the information in reading materials, it is useful to develop cognitive learning strategies through participation in group work using strategies such as analyzing, synthesizing, and reasoning to comprehend the materials. Cognitive strategies involve hypothesis testing, for example seeking the context and one's background knowledge to determine if a particular meaning makes sense or not. According to Oxford (1996), social strategies facilitate learning with others. For example, learners can ask each other questions for clarification. However, O’Malley and Chamot (1990) suggest that cognitive information-processing theory downplays social strategies for cognitive and metacognitive strategies.

For a top-down processing to be done in a reading comprehension activity, three phases should be followed: before during and after reading (Cunningham \& Creamer, 2003). They state that there are a number of activities which should be taught and practiced for the learners' comprehension. With reference to Pressley, Wharton-McDonald, MistrettaHampston, and Echevarvia (1998), they state that there is a "practice of comprehension strategies but virtually no instruction in strategy use" (p. 170). Pressley et al. also contend that "we were struck by the almost complete absence of direct instruction about comprehension strategies" (p. 172). Cunningham and Creamer (2003), however, referring to a number of strategies taken by the teacher to teach to the learners in 'before, during, and after reading' puts it this way that using group tasks after reading increases motivation and guarantees students' success in a better comprehension of the reading materials.

According to Brigham, Berkley, Simpkins, and Brigham (2007), teachers are required to adopt an interactive style of instruction which means that the learners are given sufficient guided practice to ensure that they develop their comprehension not just independent of each other but through interaction and participation in group work. Research suggests that direct and explicit teaching of comprehension strategies can result in improved comprehension. Comprehension strategies should be taught with a combination of modeling, feedback, and opportunities for later practice.

Celce-Murcia (2001) suggests a set of strategies to facilitate second language reading comprehension development. They include exposing the students to written language as much as possible, reading more extensively, providing authentic purposes for reading, using oral skills to support reading development, and providing scaffolding for learning. To Peregoy and Boyle (1997), scaffolding means the setting up of temporary supports that permit learners to take part in the complicated process of comprehending before they can do it without assistance.

One of the perspectives on learning individually and interaction is proposed by Petrovsky (1985) in his book entitled Individual and the Collective. He addresses the issue that collaboration and group work means group conformity. On 
the one hand, in collaboration the individual is "unique and derivative of the social", and on the other hand it is based on cooperative efforts to achieve common understanding. With regard to reading comprehension and collaboration, with an emphasis on extensive reading, that is reading large quantities of materials for general understanding, Renandya and Jacobs (2002) suggest a set of tasks that teachers should employ in the 'after reading' or postreading which is the third phase of reading activities in the classroom. They include both individualistic activities as well as group work. Examples of the first type are copying interesting words and expressions in a notebook, writing a letter to the author to discuss the content and expressing views on different parts and the tasks which require more group work, collaboration, and interaction are underlying and reading interesting parts aloud, share views about the book with classmates and role-playing the story. The idea that collaboration and group work play a great role in cognitive, social and affective development is very much accepted in education and developmental psychology (Donato, 2004). Learning, in this view, is seen as "improved participation in an interactive system" (Greeno, 1997).

Wenger (1998) believes that learning language through collaboration and participation in group work creates and sustains the relation of mutual accountability with other members of the community. Collaborative activities pave the way to enable the learners to participate in social activities, promote their understanding of others as well as the materials being learned, foster future learning and development through expanding participation, and create the potential for the individual's reciprocal contribution to the community (Dyson, 2000).

Kim and Hall (2002) reported a collaborative reading project for Korean learners of English. Using elaboration, questioning and paraphrasing, the learners had interactions with each other. It was found that participation in collaborative reading led to significant changes in the learners' pragmatic ability and conversational management.

Following Himes and others who supported collaboration, interaction, and group work to boost language learning in general and reading comprehension in particular, the present study was an attempt to answer the following questions first introducing collaboreading, a new concept for the learners to help each other understand reading materials better:

Q1- Do the Iranian EFL learners who use individualistic activities to enhance their comprehension improve their reading ability differently from those who use collaboreading?

Q2- Do male and female students using collaboreading outperform the other students using individualistic activities to enhance their reading comprehension?

Then based on these questions, three null hypotheses were formed:

H1- The Iranian EFL learners who use individualistic activities to enhance their comprehension do not perform in their reading test differently from those who use collaboreading.

H2- Male and female students using collaboreading do not outperform the male and female students using individualistic activities in their reading comprehension.

\section{METHOD}

\section{A. Participants}

The participants were a number of 85 EFL learners majoring in English translation at Islamic Azad Universities, Abadeh and Shiraz Branch. They were 20 male and 65 female freshmen who had taken their Reading Comprehension Course (2) at the university. Since they already had passed their Reading Comprehension Course (1), they were all assumed to know the basic reading skills including skimming and scanning.

\section{B. Instrumentation}

The NTC's Reading Comprehension Test was used as the instrument to measure the learners' improvement in reading comprehension. The test was piloted with a group of participants who were similar to the subjects of the study, and it was proved to be reliable. For its content validity, the test was reviewed by two language experts. The test was then considered as a valid and reliable instrument to be used in the study.

\section{Procedure}

In order to answer the research questions, the NTC's Reading Comprehension Test was administered along with a TOEFL reading comprehension test to a group of subjects similar to the participants of the study for the reliability purposes. Since the correlation between the two tests turned out to be 0.7 , it was concluded that the test was a reliable one. For its content validity, the test was given to two language experts to be reviewed. As they confirmed the test content, it was used as the instrument to measure the improvement of the learners' reading comprehension.

A number of 85 EFL students, 20 males and 65 females majoring in English Translation at Islamic Azad Universities, Abadeh and Shiraz Branch were selected. They were then divided into two groups. The NTC's Reading Comprehension Test was administered prior to the instruction as the pre-test. A t-test was applied to see if the participants' performance was the same or differently. The results showed that there was no significant difference in the performance of the participants in both groups. In other words, they were proved to be homogeneous.

The next phase of the study was the treatment. The participants took a four-month instruction on reading comprehension. The kind of activities the participants in each group were involved in was different. Following Kim and Hall (2002), in the first group, for the 'after reading' activity, the students were required to use elaboration, questioning and paraphrasing, and this way the learners had interactions with each other. In the second group, however, the students 
read the texts individually and answered the comprehension questions at the end of the texts for their 'after-reading' activity. At the end of the instruction, again the same test administered for the pre-test was readministered as the posttest. A one-way ANOVA was applied to the students' raw scores to see if there has been improvement in any of the groups 'performance in reading comprehension better than the other one. A sheffé test was then applied to see whether there was a significant difference in the performance of male and female students in both control and experimental groups.

\section{RESUltS AND DisCUSSION}

In order to see if the participants in the control group who were to have individualistic reading activity and the experimental group who were supposed to have interaction and collaboration in understanding the texts were homogeneous, and therefore, randomly selected, the NTC's Reading Comprehension Test was used and a t-test was applied. The results are as follows:

TABLE 1.

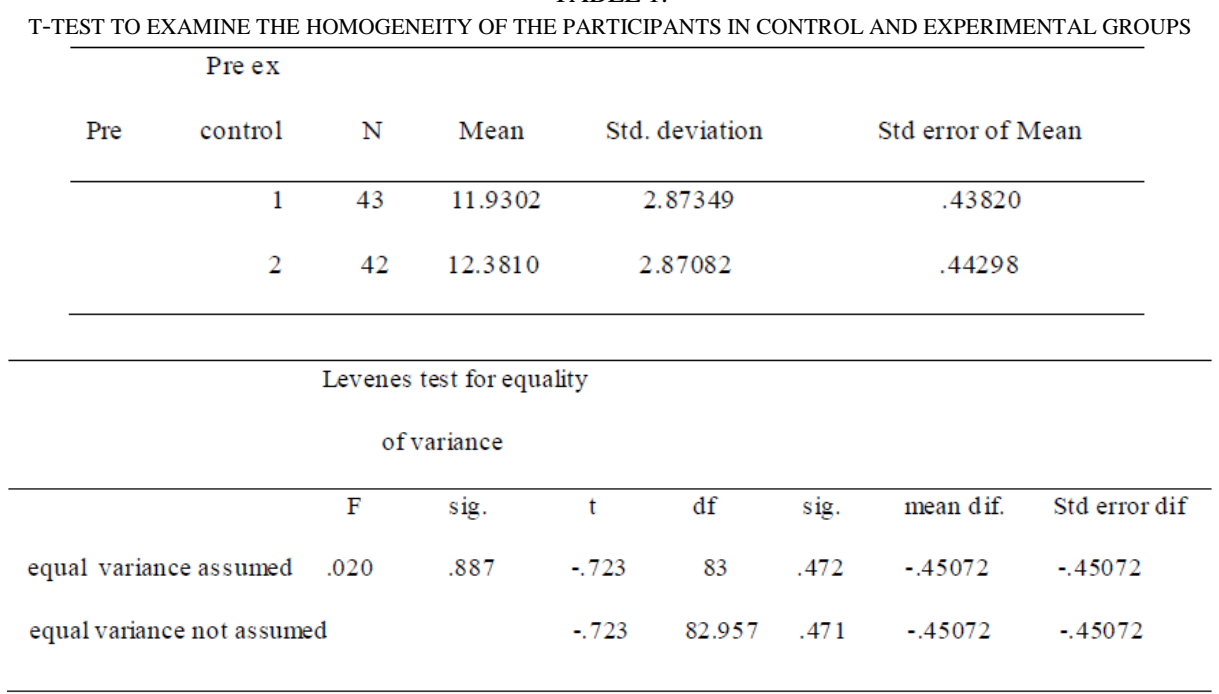

As table 1 suggests, there is not a significant difference in the performance of control and experimental group since the value of $\mathrm{F}(\mathrm{F}=.020)$ does not exceed the significance level (sig. $=.887)$. It can, therefore, be concluded that both groups were truly randomly selected. The students' raw scores in this test were also taken as the pre test.

After the instruction, the participants again took the same test they had taken in the pre-test. A one-way ANOVA was then applied to the students' scores in the pre and post test to see if there has been any improvement in the participants' performance in reading comprehension. The results are revealed in Table 2:

TABLE 2.

\begin{tabular}{|c|c|c|c|c|c|c|}
\hline & & Sum of squares & df & mean square & F & sig. \\
\hline \multirow[t]{3}{*}{ Post } & between grps & 1523.889 & 3 & 507.963 & 2.199 & 0.094 \\
\hline & within grps & 18708.064 & 81 & 230.964 & & \\
\hline & Total & 20231.953 & 84 & & & \\
\hline \multirow[t]{3}{*}{ Pre } & between grps & 12.765 & 3 & 4.255 & .510 & .677 \\
\hline & within grps & 676.247 & 81 & 8.349 & & \\
\hline & Total & 689.012 & 84 & & & \\
\hline
\end{tabular}

According to table 2, comparing the observed value of $\mathrm{F}(\mathrm{F}=2.199)$ with the significance level (sig. $=.094)$, one can come up with the idea that the difference is big enough to claim that there has been a change in the performance of the two experimental and control group. In other words, table 2 shows that there has been an improvement in the performance of the participants in the reading comprehension test in the experimental group compared to the control one. Thus, the first research hypothesis stating that the Iranian EFL learners who use individualistic activities to enhance their comprehension do not perform in their reading test differently from those who use collaboreading is rejected here. 
To find out about the performance of male and female students using individualistic and collaboreading activities to comprehend a text in both experimental and control group, a sheffe test was applied. The results are presented in table 3 as follows:

TABLE 3.

THE FOUR GROUPS' PERFORMANCE IN THE READING COMPREHENSION POST-TEST

\begin{tabular}{llc}
\hline Group & $\mathrm{N}$ & subset for alpha $=0.05$ \\
\hline 4 & 34 & 14.9706 \\
2 & 11 & 15.1562 \\
1 & 8 & 20.0000 \\
3 & 32 & 29.1250 \\
\hline
\end{tabular}

In table 3, group 4 represents females who were in the experimental group, i.e. those who used individualistic activities in comprehending the texts; group 2 represents males who had collaboreading activities in the experimental group; group 3 refers to females who enjoyed collaboreading activities; group 1 refers to males who had individualistic reading activities in the control group. As the table reveals, the first group of participants who outperformed the others were female students who had collaboreading activities in the experimental group. The second best performance belonged to the male students who enjoyed collaboration in enhancing their reading comprehension. The next two groups, males and females in the control group could not, in fact, improve their reading ability as much as those in the experimental group. Thus, the second research hypothesis stating that male and female students using collaboreading do not outperform the male and female students using individualistic activities in their reading comprehension is rejected.

\section{CONCLUSION AND PEDAGOGICAL IMPLICATIONS}

The present study is in line with Kim and Hall (2002) and Donato (2004) who support the use of interaction and collaboration in the improvement of language abilities. The results of the present study are useful for syllabus designers and materials developers who plan and develop textbooks and activities to be used in foreign language classrooms. The results also help language teachers have an empirically-based support in using pair and group work as well as other interactive activities in their reading comprehension classes.

\section{REFERENCES}

[1] Bandura, A. (1997). Self-efficacy: the exercise of control. New York: Freeman.

[2] Brigham,R., Berkley,S., Simpkins, P., \& Brigham, M. (2007) A focus on reading comprehension strategy instruction. http:// www.teachingLD.org. (accessed 25/12/2009).

[3] Block, C. C. \& Pressley, M. (2002) Introduction. In C. Block and M. Pressley (Eds), Comprehension instruction: researchbased practices. New York: Guilford Press.

[4] Brown, D. H. (2001). Teaching by principles: an interactive approach to language pedagogy (2nd ed.). New York: Pearson Education.

[5] Carter, R. \& Nunan, D.(Eds.)(2002). The Cambridge guide to teaching English to speakers of other languages. Cambridge: Cambridge University Press.

[6] Celce-Murcia, M.(Ed.)(2001). Teaching English as a second or foreign language (3rd ed.). Boston: Heinle and Heinle.

[7] Chastain, K. (1990). Developing second language skills: theory and practice ( ${ }^{\text {rd }}$ ed.). New York: HBJ publishers.

[8] Cunningham, J. W. \& Creamer, K. H. (2003). Achieving best practices in literacy education. In L.M. Morrow, L.B. Gambrell $\&$ M. Pressley (Eds.), Best practices in literacy education (2nd ed., pp. 333-346). New York: Guilford.

[9] Donato, R. (2004). Aspects of collaboration in pedagogical discourse. Annual Review of Applied Linguistics, 24, $284-302$.

[10] Dörnyei, Z. \& Ottó, I. (1998). Motivation in action: a process model of L2 motivation. Working Papers in Applied Linguistics 4 , 43-69.

[11] Duffy, G. (1993). Rethinking strategy instruction: for teachers' development and their low achievers' understandings. Elementary School Journal, 93, 231-247.

[12] Dyson, A. H. (2000). Linking writing and community development through the children's forum. In C. D. Lee \& P. Smagorinsky (Eds.), Vygotskian perspectives on literacy research (pp. 127-149). Cambridge: Cambridge University Press.

[13] Greeno, J. G. (1997). On claims that answer the wrong question. Education Researcher, 26(1), 5-17.

[14] Harmer, J. (2001). The practice of English language teaching (3rd ed.). London: Longman.

[15] Himes, D. E. (2007). How to improve reading comprehension. www.egorg.com/files/download.php. (accessed 14/12/2010)

[16] Jimenez, R., Garcia, G., \& Pearson, P. (1995). Three children, two languages, and strategic reading: case studies in bilingual/monolingual reading. American Educational Research Journal, 32, 67-97.

[17] Kim, D., \& Hall, J. K. (2002). The role on an interactive book reading program in the development of second language pragmatic competence. The Modern Language Journal, 86(3), 332-348.

[18] Kintsch, W., \& Kintsch, E. (2005). Comprehension. In S. G. Paris \& S.A. Stahl (Eds.), Children's reading: comprehension and assessment. Mahwah, NJ: Lawrence Erlbaum Associates.

[19] O’Mally, J. M. \& Chamot, A. U. (1990). Learning strategies in second language acquisition. Cambridge: Cambridge University Press.

[20] Oxford, R. L. (ed.) (1996). Language learning strategies around the world: cross-cultural perspectives. In R. Carter and D. Nunan (Eds.)(2002). The Cambridge guide to teaching English to speakers of other languages. Cambridge: Cambridge University Press. 
[21] Pearson, P. D. \& Fielding, L. (1991). Comprehension instruction. In J. C. Richards and Renandya, W. A. (Eds.) (2002) Methodology in language teaching: an anthology of current practice. Cambridge: Cambridge University Press.

[22] Peregoy, S. \& Boyle, O. (1997). Reading, writing, and learning in ESL. (2 ${ }^{\text {nd }}$ ed.). New York: Longman.

[23] Petrovsky, A. V. (1985). The collective and the individual. Moscow: Progress.

[24] Pressley, M., Wharton-McDonald, R. Mistretta-Hampston, J. \& Echevarria, M. (1998). Literacy instruction in fourth- and fifthgrade classrooms in upstate New York. Scientific Studies of Readings, 2, 159-194.

[25] Renandya, W. A. \& Jacobs, G. M. (2002). Extensive reading: why aren't we all doing it? In J. C. Richards \& W. A. Renandya (Eds.) Methodology in language teaching: an athology of current practice. Cambridge: Cambridge University Press.

[26] Scarcella, R. C. \& Oxford, R. L. (1992). The tapestry of language learning: the individual in the communicative classroom. Boston, MA.: Heinle \& Heinle.

[27] Trabasso, T. \& Bouchard, E. (2002). Teaching readers how to comprehend text strategically. In C. C. Block \& M. Pressley (Eds.), Comprehension instruction: research-based best practices. New York: Guilford Press.

[28] Vygotsky, L. S. (1986). Thought and language. Cambridge, MA: MIT Press.

[29] Wallace, C. (1992). Critical literacy awareness in the EFL classroom. In N. Fairclogh (Ed.) Critical language awareness. London: Longman.

[30] Weaver, C. (1994). Reading process and practice. $\left(2^{\text {nd }}\right.$ ed.). Portsmouth, NH: Heinemann.

[31] Wenger, E. (1998). Practice. In E. Wenger (Ed.), Communities of practice: Learning, meaning, community (pp. 43-102). New York: Cambridge University Press.

Fatemeh Behjat is a Ph.D. candidate in TEFL at Islamic Azad University, Shiraz Branch and a faculty member at Islamic Azad University, Abadeh branch, Iran. She also teaches English at Zand Institute of Higher Education and Islamic Azad University in Shiraz. She has an eight-year experience teaching English at the ILI (Iran Language Institute). She has so far presented papers at international conferences at home and abroad, published books on reading comprehension and a couple of articles in language journals. Her main area of interest is teaching and language acquisition. 